\title{
The Prognostic Value of CD49d Expression in Turkish Patients with Chronic Lymphocytic Leukemia
}

\section{Türk Kronik Lenfositik Lösemi Hastalarında CD49d Ekspresyonunun Hastalı Seyri Üzerindeki Etkisi} \author{
Mahmut Baylk ${ }^{2}$ \\ ${ }^{1}$ Erzurum Regional Training and Research Hospital, Hematology Department, Erzurum, Turkey \\ ${ }^{2}$ Marmara University, Pendik Training and Research Hospital, Hematology Department, İstanbul, Turkey
}

Ant Uzay ${ }^{1}$, Tayfur Toptaş², Işık Kaygusuz ${ }^{2}$, Emel Ekşioğlu Demiralp ${ }^{2}$, Tülin Fıratlı Tuğlular²,

\begin{abstract}
Objective: The aim of this study was to assess the prognostic value of CD49d expression in Turkish chronic lymphocytic leukemia patients.

Material and Methods: Data for 118 patients from a single center were evaluated. In all, the study included 73 patients for whom complete clinical follow-up data, and flow cytometry test results for CD5/19, CD23/43, CD38, Zap70, Kappa, and Lambda light chains, and CD49d were available. The effect of the level of CD49d expression on overall survival (OS) and time to treatment (TTT) was investigated retrospectively.

Results: Patients with high CD49d expression $(\geq 30 \%)$ had more advanced disease at the time of diagnosis (median Rai stage 3 vs. Rai stage $1, P=0.03$ ). Patients resistant to treatment had higher CD49d expression than patients that responded to treatment (mean CD49d expression of $58 \%$ vs. $46 \%, P=0.08$ ). The level of CD49d expression was not associated with OS or TTT.

Conclusion: The study's findings show that the patients with high CD49d expression at the time of diagnosis had more advanced disease and poorer response to therapy; however, their overall survival did not differ from that of the patients with advanced disease stage, but lower levels of CD49d expression.
\end{abstract}

Key Words: Chronic lymphocytic leukemia, CD49d, Prognosis

Özet

Amaç: Bu çalışmada, kronik lenfositik lösemi hastalarında, CD49d ekspresyonun hastalık seyri üzerindeki etkisi araştırılmıştır.

Gereç ve Yöntemler: Merkezimizde kayıtlı 118 hastanın laboratuvar ve tıbbi kayıtları değerlendirmiştir. CD5/CD19, CD23/CD43, CD38, Zap-70, kappa, lambda ve CD49d ekspresyonuna bakılmış olan toplam 73 hasta çalışmaya dahil edilmiştir. Bunlardan, CD49d'nin hastalık seyri üzerindeki etkileri geriye dönük olarak araştırılmıştır.

Sonuç: CD49d'yi yüksek oranda ( $\geq \% 30$ ) eksprese eden hastaların daha ileri evrede oldukları görülmüştür (ortanca Rai evre 3'e karşı Rai evre 1, p= 0.03). İki ve üç basamak tedavi alan hastaların, sadece bir basamak tedavi alanlara göre

Address for Correspondence: Ant UZAY, M.D.,

Erzurum Bölge Eğitim ve Araştırma Hastanesi, Hematoloji Bölümü Erzurum, Turkey

Phone: +90 4422325290 E-mail: teteantuzay@yahoo.com

Received/Geliş tarihi : September 19, 2011

Accepted/Kabul tarihi : October 25, 2011 
daha yüksek oranda CD49d eksprese ettikleri görülmüştür (\%58'e karşı \%46, p= 0.08). İleri evre hastalarda, CD49d ekspresyonun, tedaviye kadar geçen zaman ve toplam să̆ kalım üzerinde etkisi bulunmamıştır.

Bulgular: Çalışmamızda, yüksek CD49d ekspresyonu ileri evre ve kötü tedavi yanıtı ile ilişkili bulunmasına rağmen, düşük CD49d ekspresyonu gösteren diğer ileri evre hastalarla karşılaştırıldığında, tedaviye kadar geçen zaman ve toplam sağ kalım açısından belirleyici olmadığı görülmüştür.

\section{Anahtar Sözcükler: Kronik lenfositik lösemi, CD49d, Prognoz}

\section{Introduction}

Chronic lymphocytic leukemia (CLL) is the most prevalent malignancy in the elderly. As populations in developed countries continue to age, the disease is becoming a greater burden for national health care systems. Even though CLL is classified as an indolent lymphoma, for practical purposes it is a unique clinical entity [1]. The disease's clinical presentation is diverse. There are welldefined CLL classification systems (i.e. Rai and Binet), but some patients with the same stage of disease have different clinical outcomes. This highlights the need for a better understanding of the histological and genetic properties of CLL cells.

Determination of prognostic parameters during the early stages of the disease provides valuable clues concerning the disease course and aids in establishing an effective treatment strategy. The most commonly used prognostic parameters at present are ZAP-70, IGHV mutation status, CD38 expression, and cytogenetic abnormalities, all of which are associated with early disease progression [2-6]. The role of these surface antigens in cell survival is not fully known. Nevertheless, many studies have shown that these antigens play an important role in cell-to-cell signaling, interaction with the microenvironment, and cytokinemediated effects [7].

It is interesting that CLL cells can proliferate steadily and become resistant to apoptosis in vivo, but become susceptible when exposed to an in vitro environment [8]. This suggests that there are various factors that promote cell-microenvironment interaction, enhancing cell proliferation and survival [9]. Some of the most important factors responsible for survival of CLL cells are integrins (alfa4, betal integrin, and CD49d), and ligands (VCAM-1, fibronectin) $[10,11]$

CD49d is a surface antigen of the integrin family (integrin- $\alpha 4$ ) that plays an important role in cell survival, activation, and migration. Interacting with fibronectin and VCAM-1, CD49d bonds B-cells to the marrow microenvironment and stromal cells found in the germinal centers of lymphoid follicles [12]. Except for the anchorage functions, it also serves as a signaling receptor that up regulates Bcl-2 transcription, which in turn inhibits apoptosis $[13,14]$. Many researchers have investigated CD49d expression in CLL, and its impact on prognosis and overall survival (OS). Expression of CD49d in CLL differs from that of other B-cell malignancies, and is generally lower than that of normal B-cells [15]. Some studies report that high CD49d expression is associated with advanced-stage disease and the presence of lymphadenopathy [16-18]. Based on these findings, other researchers studied the effect of CD49d expression on OS and its potential as a prognostic parameter. Shanafelt et al. reported that high CD49d expression (>45\%) is strongly correlated with poor prognosis and shorter time to treatment (TTT) in previously untreated CLL patients [19]. CD49d is increasing in popularity as a molecule in research on CLL prognostic markers to such an extent that some researchers think it is a major factor to which a prognostic antigen profiling score should be assigned [20]. The aim of the present study was to examine the prognostic value of CD49d expression in Turkish CLL patients.

\section{Materials and Methods}

\section{Patients}

This study included CLL patients that were followedup at Marmara University Hospital, Istanbul, Turkey, between 1998 and 2008. Clinical and laboratory data for 118 patients were obtained, of which 73 had sufficient data, including immunophenotyping and pathology findings, as well as well-documented clinical follow-up results. Each participant provided written informed consent before undergoing any procedure. The study protocol was in compliance with the principles of Good Clinical Practice and was approved by the Marmara University Hospital Institutional Review Board.

Diagnostic criteria for CLL was as follows: an absolute lymphocyte count $>5000 \mathrm{~mm}^{-3}$ in peripheral blood; a monoclonal lymphocytic population in peripheral blood, lymph node, or bone marrow (defined as $\mathrm{CD}^{+} / \mathrm{CD}^{-} 0^{-} /$ $\left.\mathrm{CD} 19^{+} / \mathrm{CD} 22^{+} / \mathrm{CD} 23^{+}\right)$in $>30 \%$ of lymphocytes. Patients were classified according to the Rai staging system for CLL, 
as follows: stage 0: only peripheral blood lymphocytosis $>15000 \mathrm{~mm}^{-3}$ or lymphocytes $>40 \%$ in bone marrow; stage 1 : stage 0 and lymphadenopathy; stage 2 : stage 0 or 1 and splenomegaly, hepatomegaly, or both; stage 3: stage 0-2 and $\mathrm{Hb}<11 \mathrm{~g} \mathrm{dL}^{-1}$; stage 4: stage 0-3 and a platelet level $<100,000109 / \mathrm{L}$. Only patients in whom treatment was indicated according to National Cancer Institute-Working Group (NCI-WG) criteria received treatment [21].

\section{Immunophenotypic analysis}

Prognostic evaluation was based on Rai stage and flow cytometric parameters, including CD38, Zap-70, and CD49d expression. CD49d, Zap-70, and CD38 were analyzed via flow cytometry (FACS CANTO®-Becton Dickinson, Mountain View, CA, USA) using direct immunofluorescence labeling. After gating CDlla (+) cells (total lymphocytes), the $\mathrm{CD} 5^{+} / \mathrm{CD} 19^{+}$population as a percentage (CLL cells) was calculated and CD49 $\mathrm{d}^{+}$cells were gated in that population, providing the actual percentage of CD49d expression among the CLL cells. Similarly, Zap-70 expression was analyzed on $\mathrm{CD} 20^{+}$cells and CD38 expression was analyzed on CD22+ lymphocytes. High-level expression cut-off values for CD49d, Zap-70, and CD38 were set at $\geq 30 \%, \geq 20 \%$, and $\geq 20 \%$, respectively.Cytogenetic data were inconsistent and scarce, and were not included.

None of the patients was treated with autologous or allogeneic stem cell transplantation. Treatments given to patients with progressive disease were highly heterogeneous. Whereas some patients received fludarabine-based treatments-with or without rituximab-others had chlorambucil- or CHOP-based regimens. Considering the small study population, we had to exclude the effects of treatment on prognosis.

\section{Statistical analysis}

Normality of the distribution of data was evaluated using the binominal and Ryan Joiner's tests. Data are presented as mean, median, standard error of mean, standard deviation, range, and 95\% confidence interval. Two-tailed $P$ values $<0.05$ were considered statistically significant. Parametric and non-parametric variables with abnormal distribution were evaluated using the Mann-Whitney $\chi^{2}$, Yates corrected $\chi^{2}$, Fisher's exact, and KolmogorovSmirnov's tests. TTT and OS were estimated according to the Kaplan-Meier method, and analyzed via univariate and multivariate Cox proportional hazards models. TTT was calculated as the time from diagnosis to the start of firstline treatment or last contact. OS was estimated as the time from diagnosis to death from any cause or last contact. All analyses were performed using SPSS v.15.0 for Win- dows (SPSS Inc. Chicago IL, USA) and Stata/SE v.10.0 for Macintosh (Stata Corporation, TX, USA).

\section{Results}

Among the 73 patients, 25 were female (34.3\%) and 48 were male (65.7\%). Median age was 64 years (range: $38-83$ years). Median follow-up was 36 months (range: $2-240$ months). In all, 22\% ( $=16)$ of the patients had advanced-stage disease (Rai stage 3 and 4). Patient characteristics are shown in Table 1 . There weren't any differences in age or gender between the patients with CD49d expression $\geq 30 \%$ and $<30 \%$ (median age: 64 years vs. 63.5 years, $\mathrm{P}=0.67$, respectively; male/female $23 / 12$ vs. $25 / 13, P=0.99$, respectively)

The distribution of high CD49d expression according to Rai stage showed that patients with CD49d expression $\geq 30 \%$ had a significantly higher median Rai stage at the time of diagnosis than those with CD49d expression $<30 \%$ (median Rai stage 3 vs. $1, P=0.034$ ). Analysis of the correlation between high CD49d expression and TTT showed that as CD49d expression increased TTT decreased, but the difference between patients with high and low CD49d
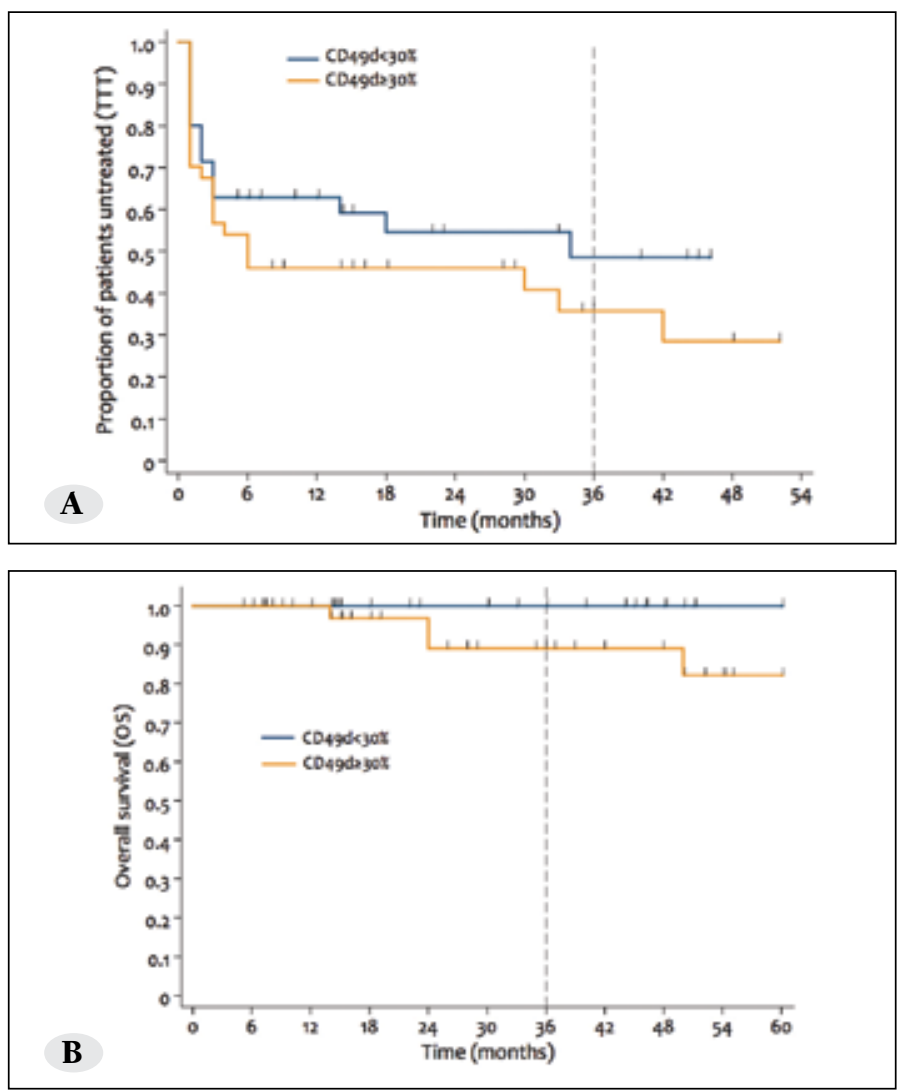

Figure 1: The effect of CD49d expression level on (A) TTT and (B) OS. 
expression was not statistically significant (Figure la, Table 1). Patients with higher CD49d expression had longer OS, but the difference between patients with high and low CD49d expression was not statistically significant (Figure 1b, Table 1). Patients those were resistant to treatment (patients those received $>1$ line treatment) had higher CD49d expression than patients that received only 1 line treatment, but the difference in CD49d expression was not statistically significant (median CD49d expression: $44.5 \%$ vs. $25 \%$, respectively, $\mathrm{P}=0.58$ ).

The difference in TTT and OS between the patients with high and low CD49d expression that were in the same disease stage was not statistically significant (Figure $2 \mathrm{a}$ and $\mathrm{b}$ ). The present study also investigated the effect of $\mathrm{CD}^{2} 8^{+} / \mathrm{CD} 49 \mathrm{~d}^{+}$co-expression on TTT and OS. Patients with $\mathrm{CD} 38^{+} / \mathrm{CD} 49 \mathrm{~d}^{+}$coexpression had shorter TTT and OS, but only the difference in TTT was statistically significant (Figure $3 \mathrm{a}$ and $\mathrm{b}$ ). Multivariate analysis showed that only advanced Rai stage was associated with shorter OS and TTT (Table 2).
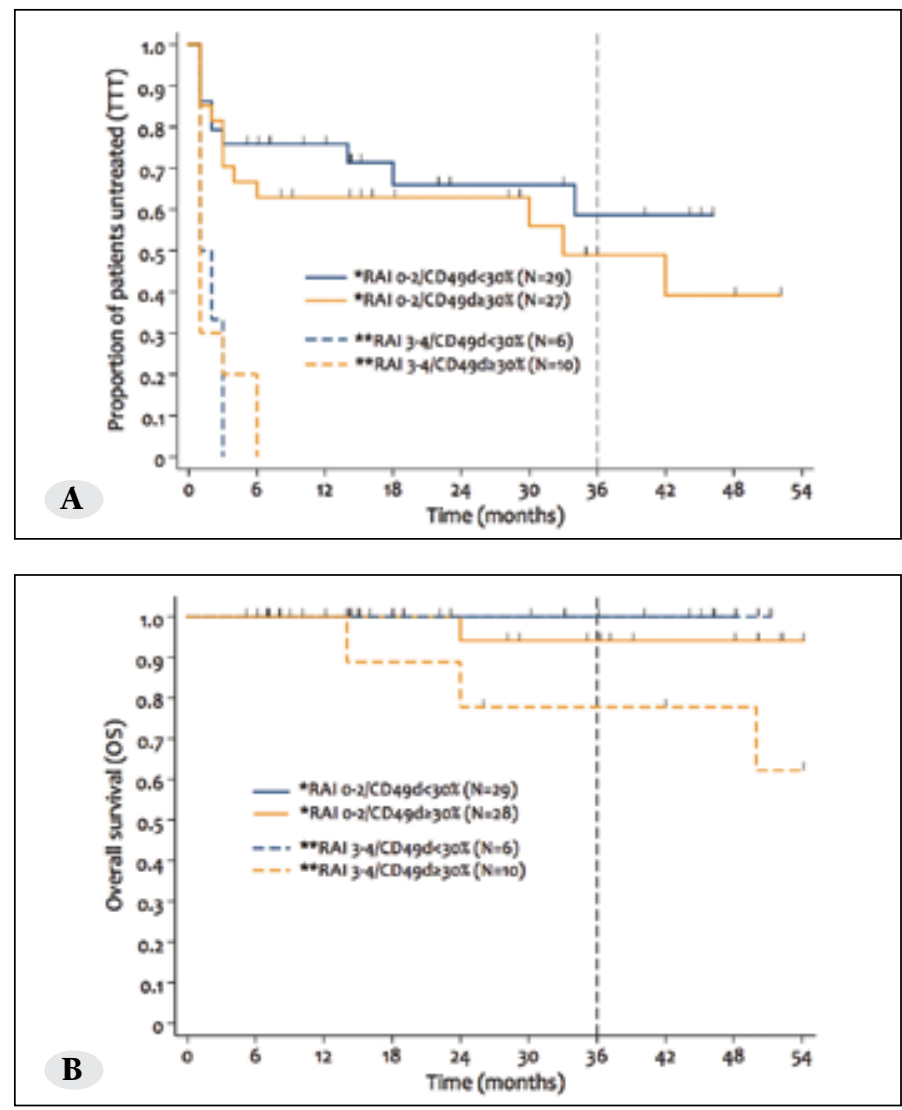

Figure 2: The effect of CD49d expression level on (A) TTT [ ${ }^{*} \mathrm{p}=0.36,{ }^{*} \mathrm{p}=0.66\left(\log\right.$-rank)] and (B) OS [ ${ }^{*} \mathrm{p}=0.33$, ** $\mathrm{p}=0.18$ (log-rank)] in different RAI stages.

\section{Discussion}

The aim of the present study was to determine the prognostic value of CD49d expression in Turkish CLL patients, . Rai disease stage was inversely correlated with OS and TTT. Three of the most commonly used flow cytometric parameters-CD38, Zap-70, and CD49-were included as parameters indicative of poor prognosis, and their effect on TTT and OS was investigated. Lymphocytosis at the time of diagnosis and high Zap-70 expression were not associated with shorter OS or shorter TTT.High expression of Zap-70 is a well-known parameter indicating poor prognosis [6]; however, an arbitrary cut-off value of $20 \%$ was not associated with a negative effect on the disease course in the present study. Had we used a Zap-70 positivity cut-off value $\geq 30 \%$, the results would probably revealed the negative prognostic value of the marker more clearly

CD49d was investigated alone and together with CD38 expression in order to understand its effect on the disease course. Some researchers used $>45 \%$ as a cut-off value [19], whereas many others used $>30 \%$; as such, the latter cut-off value was used in the present study $[20,22]$. High
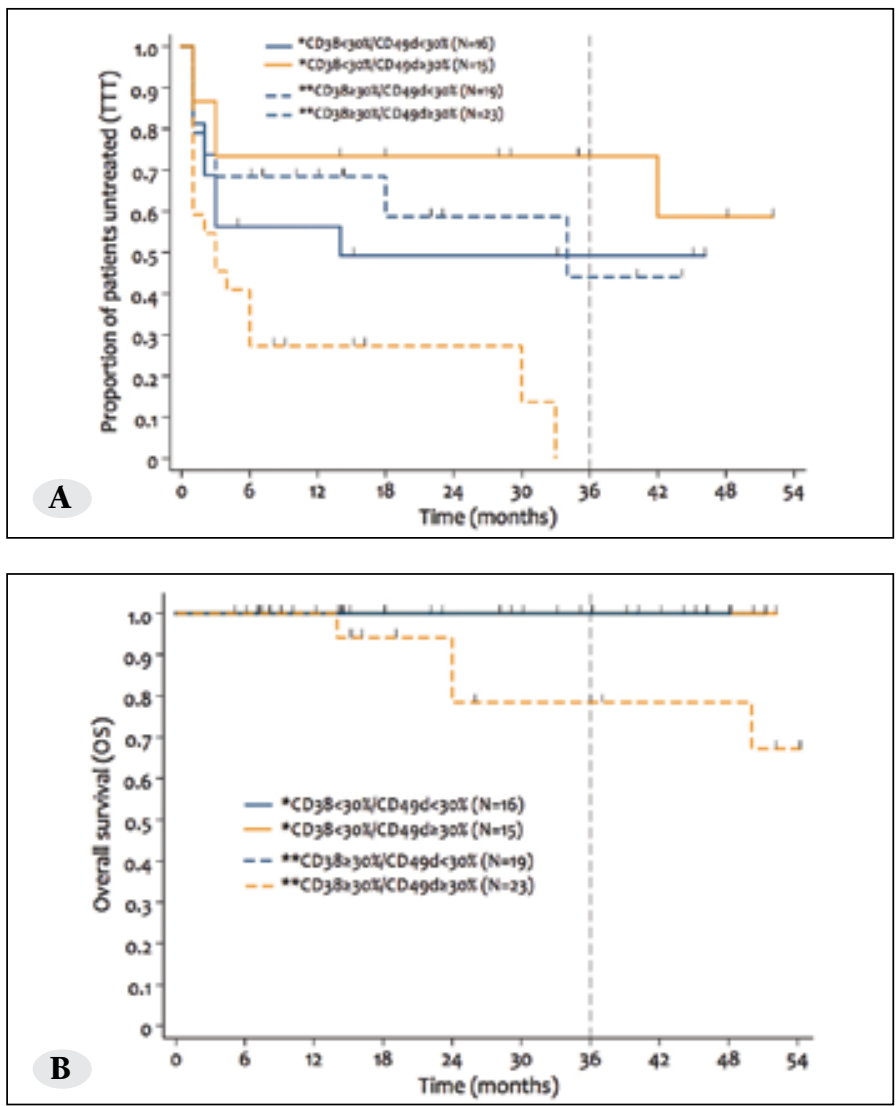

Figure 3: The effect of CD38/CD49d co-expression status on (A) TTT [ ${ }^{*} \mathrm{p}=0.33,{ }^{*} \mathrm{p}=0.004$ (log-rank)] and (B) OS [* $\mathrm{p}=1.0$, $* * \mathrm{p}=0.13$ (log-rank)]. 
Table 1: Clinical characteristics of 73 CLL patients

\begin{tabular}{|c|c|c|c|c|c|}
\hline Variable & Number (\%) & 3-y TTT (\%) & P (log-rank) & $3-y$ OS (\%) & P (log-rank) \\
\hline \multicolumn{6}{|l|}{ Follow-up } \\
\hline Median & 36 months & & & & \\
\hline Range & 2-240 months & & & & \\
\hline \multicolumn{6}{|l|}{ Age } \\
\hline Median & 64 years & & & & \\
\hline Range & $38-83$ years & & & & \\
\hline$<65$ years & $39(53.4)$ & 41.8 & .37 & 100 & .39 \\
\hline$\geq 65$ years & $34(46.6)$ & 42.0 & & 88.6 & \\
\hline \multicolumn{6}{|l|}{ Gender } \\
\hline Female & $25(34.3)$ & 35.1 & .31 & 95.2 & .66 \\
\hline Male & $48(65.7)$ & 45.4 & & 93.3 & \\
\hline \multicolumn{6}{|l|}{ RAI } \\
\hline $0-2$ & $57(78.1)$ & 54.1 & $<.001$ & 97.0 & .036 \\
\hline $3-4$ & $16(21.9)$ & 0 & & 85.1 & \\
\hline \multicolumn{6}{|c|}{ Initial lymphocytosis } \\
\hline$\geq 25 \times 10^{3} / \mu \mathrm{L}$ & $38(52.1)$ & 33.7 & .21 & 88.6 & .055 \\
\hline$<25 \times 10^{3} / \mu \mathrm{L}$ & $35(47.9)$ & 52.2 & & 100 & \\
\hline \multicolumn{6}{|l|}{ ZAP-70 } \\
\hline$<20 \%$ & $15(20.6)$ & 46.7 & .91 & 92.3 & 1.0 \\
\hline$\geq 20 \%$ & $58(79.4)$ & 39.0 & & 93.9 & \\
\hline \multicolumn{6}{|l|}{ CD38 } \\
\hline$<30 \%$ & $31(42.5)$ & 61.0 & .031 & 100 & .022 \\
\hline$\geq 30 \%$ & $42(57.5)$ & 20.5 & & 86.4 & \\
\hline \multicolumn{6}{|l|}{ CD49d } \\
\hline$<30 \%$ & $35(48.0)$ & 48.4 & .21 & 100 & .069 \\
\hline$\geq 30 \%$ & $38(52.0)$ & 35.7 & & 89.1 & \\
\hline
\end{tabular}

TTT and OS denote time-to-treatment and overall survival, respectively.

Table 2: Cox proportional hazard model for OS and TTT

$\begin{array}{lccc}\text { Variable } & \text { HR } & 95 \% \text { CI } & \text { p } \\ \text { TTT } & & & \\ \text { RAI } & 5.10 & 2.51-10.39 & <.001 \\ \text { CD38 } & 1.84 & .91-3.59 & .093 \\ \text { OS } & & & \\ \text { RAI } & 4.33 & .45-42.02 & .21\end{array}$

TTT and OS denote time-to-treatment and overall survival, respectively.

CD49d expression was associated with more advanced disease stages, as previously reported [16]. Even though high CD49d expression was associated with shorter TTT and OS, the results were not statistically significant, which is contrast to previous published data by other investigators $[19,22]$.

Shanafelt and Gattei studied CD49d as an independent prognostic factor in untreated CLL patients. They reported that high CD49d expression was associated with shorter OS and treatment-free survival (TFS) [19,22]. In our study, the patients who were in early disease stage (Rai 0-2) had significantly better OS and TTT than those in adveanced disease stage (Rai 3-4), regardless of the level of CD49d expression. As the advanced disease patients had higher CD49d expression at the time of diagnosis, it is logical to conclude that the negative effect of high CD49d expression on OS and TTT may not have been due to CD49d per se, but to more advanced disease stage. Shanafelt and Gattei investigated CD49d expression by assigning patients into risk groups, but their results do not reveal clearly the clinical course in low-risk patients with high CD49d expression $[19,22]$ The present study also investigated the effect of CD49d expression in highrisk patients and observed that there wasn't a difference in OS or TTT between the high-risk patients with high and 
low CD49d expression, which supports our hypothesis that disease stage, not CD49d expression, is a predictive prognostic factor.

Advanced-stage disease is associated with high tumor mass, which in turn is associated with extensive organ and tissue invasion by CLL cells. Thus, in patients with advanced-stage disease there should be more production of integrins and ligands, as expected. This might explain why CD49d expression is associated with advanced stage disease. The actual prognostic value of high CD49d expression would become more definitive if investigated in earlystage CLL patients. As low-risk (Rai 0-2) CLL patients have long-term OS and TFS, it is extremely challenging to perform a prospective study on the effect of CD49d expression on disease course. It is known that high CD49d expression is associated with advanced-stage disease and shorter OS and TTT; however, most of these patients are diagnosed with advanced CLL and are expected to have limited survival anyway. It would be interesting to examine how the disease progresses in low-risk CLL patients that have high CD49d expression at the time of diagnosis. If early-stage patients with high CD49d expression are shown to have more rapid disease progression, then the prognostic value of CD49d expression would be firmly established.

CD38 expression in CLL patients is associated with shorter OS and poor response to treatment [3-5]. Some studies reported that CD49d expression is correlated with CD38 expression, $[23,24]$. The present study analyzed the prognostic effect of $\mathrm{CD}^{2} 8^{+} / \mathrm{CD} 49 \mathrm{~d}^{+}$co-expression on TTT and OS. only patients with high levels of coexpression (CD38 $\geq 30 \%$ and CD49d $\geq 30 \%$ ) had shortOS with no statistical significance, these patients had also significantly short TTT. These findings show that $\mathrm{CD}^{2} 8^{+} / \mathrm{CD} 49 \mathrm{~d}^{+} \mathrm{co}-$ expression had a negative effect on disease course, as previously reported $[23,24]$. The small cohort included in the present study might have prevented observation of the probable prognostic importance of CD49d. Another important limitation of the present study is the heterogeneity of the treatment modalities provided to the patients with progressive disease, which is why it was not possible to investigate the heterogeneous treatment effect on prognosis.

In conclusion, the present findings indicate that CD49d expression may not be a completely independent prognostic factor, but probably should be evaluated in conjunction with CD38 expression. Currently, there is a lack of solid statistical evidence to prove that and as such, additional prospective research is required in order to determine if CD $38^{+} / C D 49 \mathrm{~d}^{+}$co-expression is a stronger prognostic factor than CD49d expression alone.

\section{Conflict of Interest Statement}

The authors of this paper have no conflicts of interest, including specific financial interests, relationships, and/ or affiliations relevant to the subject matter or materials included.

\section{References}

1. Caligaris-Cappio F, Hamblin TJ. B-cell chronic lymphocytic leukemia: A bird of a different feather. J Clin OncoI 1999;17:399-408.

2. Molica S, Levato D, Dattilo A, Mannella A. Clinicoprognostic relevance of quantitative immunophenotyping in B-cell chronic lymphocytic leukemia with emphasis on the expression of CD20 antigen and surface immunoglobulins. Eur J Haematol 1998;60:47-52.

3. Del Poeta G, Maurillo L, Venditti A, Buccisano F, Epiceno AM, Capelli G, Tamburini A, Suppo G, Battaglia A, Del Principe MI, Del Moro B, Masi M, Amadori S. Clinical significance of CD38 expression in chronic lymphocytic leukemia. Blood 2001;98:2633-2639.

4. Ibrahim S, Keating M, Do KA, O’Brien S, Huh YO, Jilani I, Lerner S, Kantarjian HM, Albitar M. CD38 expression as an important prognostic factor in B-cell chronic lymphocytic leukemia. Blood 2001;98:181-186.

5. Chevallier P, Penther D, Avet-Loiseau H, Robillard N, Ifrah N, Mahé B, Hamidou M, Maisonneuve H, Moreau P, Jardel H, Harousseau JL, Bataille R, Garand R. CD38 expression and secondary $17 \mathrm{p}$ deletion are important prognostic factors in chronic lymphocytic leukaemia. Br J HaematoI 2002;116:142-150

6. Dürig J, Nückel H, Cremer M, Führer A, Halfmeyer K, Fandrey J, Möröy T, Klein-Hitpass L, Dührsen U. ZAP-70 expression is a prognostic factor in chronic lymphocytic leukemia. Leukemia 2003;17:2426-2434.

7. Calgaris-Cappio F. Role of the microenvironment in chronic lymphocytic leukemia. Br J Haematol 2003;123:380-388.

8. Kay NE, Shanafelt TD, Strege AK, Lee YK, Bone ND, Raza A. Bone biopsy derived marrow stromal elements rescue chronic lymphocytic leukemia B-cells from spontaneous and drug induced cell death and facilitates an "angiogenic switch". Leuk Res 2007;31:899-906.

9. Ghia P, Granziero L, Chilosi M, Caligaris-Cappio F. Chronic $\mathrm{B}$ cell malignancies and bone marrow microenvironment. Semin Cancer Biol 2002;12:149-155.

10. Lagenaux L, Delforge A, De Bruyn C, Bernier M, Bron D. Adhesion to bone marrow stroma inhibits apoptosis of chronic lymphocytic leukemia cells. Leuk Lymphoma 1999;35:445-453. 
11. De la Fuente MT, Casanova B, Garcia-Gila M, Silva A, GarciaPardo A. Fibronectin interaction with alpha4betal integrin prevents apoptosis in B cell chronic lymphocytic leukemia: Correlation with Bcl-2 and Bax. Leukemia 1999;13:266274.

12. Rose DM, Han J, Ginsberg MH. Alpha4 integrins and the immune response. Immunol Rev 2002;186:118-124.

13. Koopman G, Keehnen RM, Lindhout E, Newman W, Shimizu Y, van Seventer GA, de Groot C, Pals ST. Adhesion through the LFA-1 (CD11a/CD18)-ICAM-1 (CD54) and the VLA-4 (CD49d)-VCAM-1 (CD106) pathways prevents apoptosis of germinal center B cells. J Immunol 1994;152:3760-3767.

14. Hayashida K, Shimaoka Y, Ochi T, Lipsky PE. Rheumatoid arthritis synovial stromal cells inhibit apoptosis and up-regulate Bcl-xL expression by B cells in a CD49/CD29CD106-dependent mechanism. J Immunol 2000;164:11101116.

15. Baldini L, Cro L, Calori R, Nobili L, Silvestris I, Maiolo AT. Differential expression of very late activation antigen-3 (VLA-3)/VLA-4 in B-cell non-Hodgkin lymphoma and B-cell chronic lymphocytic leukemia. Blood 1992;79:26882693.

16. Eksioğlu-Demiralp E, Alpdoğan O, Aktan M, Firatli T, Oztürk A, Budak T, Bayik M, Akoğlu T. Variable expression of CD49d antigen in B cell chronic lymphocytic leukemia is related to disease stages. Leukemia 1996;10:1331-1339.

17. Behr SI, Korinth D, Schriever F. Differential adhesion pattern of B cell chronic lymphocytic leukemia cells. Leukemia 1998;12:71-77.

18. Lúcio PJ, Faria MT, Pinto AM, da Silva MR, Correia Júnior ME, da Costa RJ, Parreira AB. Expression of adhesion molecules in chronic B-cell lymphoproliferative disorders. Haematologica 1998;83:104-111.
19. Shanafelt TD, Geyer SM, Bone ND, Tschumper RC, Witzig TE, Nowakowski GS, Zent CS, Call TG, Laplant B, Dewald GW, Jelinek DF, Kay NE. CD49d expression is an independent predictor of overall survival in patients with chronic lymphocytic leukaemia: A prognostic parameter with therapeutic potential. Br J Haematol 2008;140:537546.

20. Zucchetto A, Bomben R, Dal Bo M, Sonego P, Nanni P, Rupolo M, Bulian P, Dal Maso L, Del Poeta G, Del Principe MI, Degan M, Gattei V. A scoring system based on the expression of six surface molecules allows the identification of three prognostic risk groups in B-cell chronic lymphocytic leukemia. J Cell Physiol 2006;207:354-363.

21. Cheson BD, Bennett JM, Grever M, Kay N, Keating MJ, O'Brien S, Rai KR. National Cancer Institute-sponsored Working Group guidelines for chronic lymphocytic leukemia: re- vised guidelines for diagnosis and treatment. Blood 1996;87:4990-4997.

22. Gattei V, Bulian P, Del Principe MI, Zucchetto A, Maurillo L, Buccisano F, Bomben R, Dal-Bo M, Luciano F, Rossi FM, Degan M, Amadori S, Del Poeta G. Relevance of CD49d protein expression as overall survival and progressive disease prognosticator in chronic lymphocytic leukemia. Blood 2008;111:865-873.

23. Dürig J, Nückel H, Hüttmann A, Kruse E, Hölter T, Halfmeyer K, Führer A, Rudolph R, Kalhori N, Nusch A, Deaglio S, Malavasi F, Möröy T, Klein-Hitpass L, Dührsen U. Expression of ribosomal and translation-associated genes is correlated with a favorable clinical course in chronic lymphocytic leukemia. Blood 2003;101:2748-2755.

24. Pittner BT, Shanafelt TD, Kay NE, Jelinek DF. CD38 expression levels in chronic lymphocytic leukemia B cells are associated with activation marker expression and differential responses to interferon stimulation. Leukemia 2005;19:2264-2272. 